\title{
LEVINASIAN ETHICS AND ANIMAL RIGHTS
}

\section{Jonathan Crowe*}

What can we say, in good faith, about the moral status of animals? This article explores the above question through the prism of Emmanuel Levinas' theory of ethics. I begin by examining the ambiguous position of non-human animals in Levinas' writings. I argue that Levinas' theory is best read as suggesting that nonhumans present claims for recognition as ethical beings, but that these demands have a different character to those presented by humans. I then explore the implications of Levinas' view of ethics for the structure of moral reasoning. I contend that Levinas theory yields a conception of moral reasoning as reflective, good faith engagement with primordial social judgements of ethical significance. In the final part of the article, I suggest that it is both possible and constructive to thematise the ethical claims of non-human animals in the language of rights. Indeed, from a Levinasian perspective, animal rights might properly be viewed as a model for the notion of human rights, since they capture the essential asymmetry of the ethical encounter.

Que peut-on dire, de bonne foi, au sujet du statut moral des animaux? Cet article examine cette question à travers le prisme de la théorie d'éthique d'Emmanuel Levinas. J'examine d'abord la position ambiguë des animaux non humains dans les écrits de Levinas. Je soutiens que la meilleure façon d'interpréter la théorie de Levinas, c'est qu'elle suggère qu'il y a des raisons de reconnaître un caractère éthique aux êtres non humains, mais que ces raisons different de celles relatives aux êtres humains. J'examine ensuite les implications de la façon dont Levinas voit l'éthique pour la structure du raisonnement moral. Je prétends que la théorie de Levinas présente une conception du raisonnement moral comme étant un engagement réflectif, de bonne foi, avec des jugements sociaux primordiaux ayant une portée éthique. Dans la dernière partie de l'article, je suggère quil est possible et quil est constructif de faire une thématique des prétentions éthiques d'animaux non humains en utilisant le langage des droits. En fait, dans la perspective de Levinas, on peut correctement voir les droits des animaux comme modèle pour la notion des droits de la personne, car ils saisissent l'asymétrie essentielle de la rencontre éthique.

* Senior Lecturer and Fellow, Centre for Public, International and Comparative Law, T. C. Beirne School of Law, University of Queensland. I would like to thank Bill Conklin, Julian Lamont, Suri Ratnapala, Lisa Toohey and the two anonymous reviewers for their helpful comments. An earlier version of this article was presented at the Emmanuel Levinas Centenary Conference hosted by the European Philosophy Research Group at the University of Queensland in June 2006. I am grateful to all who participated in the discussion.

(2008) 26 Windsor Y.B. Access Just. 


\section{INTRODUCTION}

What can we say, in good faith, about the moral status of animals? Understood through the prism of Emmanuel Levinas' theory of ethics, the question requires us to pay close attention to the nature of our encounter with the non-human Other. There has been significant debate as to whether Levinas' theory can accommodate the ethical interests of non-humans. ${ }^{1}$ In this article, I argue that Levinas' work can be read as supporting not only a view of animals as ethical beings, but a theory of animal rights.

Non-human animals occupy a problematic position in Levinas' writings. Levinas' explicit comments on the ethical status of animals are ambiguous, as we will see in more detail below. Although some theorists are more optimistic than others about the potential of Levinas' theory to support the ethical personality of animals, many commentators have depicted his account as fundamentally human-oriented. My aim in this article is to cast doubt on this interpretation. I argue that Levinas' theory is best read as suggesting that non-human animals present claims for recognition as ethical beings, but that these demands have a different character to those presented by humans.

What do we have to gain by pursuing a Levinasian account of the ethical status of non-human animals? After all, those seeking a philosophical basis for the view that animals are entitled to moral consideration have a range of theories to choose from, including the well-known accounts offered by Peter Singer and Tom Regan. ${ }^{2}$ However, there are at least two good reasons for persisting with a Levinasian perspective on this area.

The first reason has to do with what Levinas' comments on non-human animals tell us about his broader ethical theory. An examination of the ambiguous position of non-humans in Levinas' writings holds the potential to cast light on his important notions of alterity, proximity and the face, as well as illuminating the role of suffering in his account. We might therefore use this enquiry to deepen our understanding not only of the ethical status of animals, but also of ethical relations between humans.

A Levinasian account of the ethical status of non-human animals also offers

1 See e.g. Peter Atterton, "Face to Face with the Other Animal?" in Peter Atterton, Matthew Calarco and Maurice Friedman, eds., Levinas and Buber: Dialogue and Difference (Pittsburgh: Duquesne University Press, 2004); Matthew Calarco, "Deconstructionism is not Vegetarianism: Humanism, Subjectivity and Animal Ethics" (2004) 36 Continental Philosophy Review 175; David Clark, "On Being 'the Last Kantian in Nazi Germany': Dwelling with Animals After Levinas" in Barbara Gabriel and Susan Ilcan, eds., Postmodernism and the Ethical Subject (Montreal: McGill-Queen's University Press, 2004); Christian Diehm, "Facing Nature: Levinas Beyond the Human" (2000) 44 Philosophy Today 51; John Llewelyn, "Am I Obsessed By Bobby? Humanism of the Other Animal" in Robert Bernasconi and Simon Critchley, eds., Re-Reading Levinas (Bloomington: Indiana University Press, 1991) [Llewelyn]; Jacques Derrida and Jean-Luc Nancy, "'Eating Well' or the Calculation of the Subject: An Interview with Jacques Derrida" in Eduardo Cadava, Peter Connor and Jean-Luc Nancy, eds., Who Comes After the Subject (London: Routledge, 1991).

2 See Peter Singer, Animal Liberation (New York: Avon Books, 1975); Tom Regan, The Case for Animal Rights (Berkeley: University of California Press, 1983). For another influential discussion of animal rights, see Robert Nozick, Anarchy, State and Utopia (Oxford: Basil Blackwell, 1974) at $35-42$. 
us a novel framework for exploring the role of rights in moral and political discourse. Levinas offers us an account of moral reasoning that is fundamentally Other-oriented. This provides an important counterpoint to traditional liberal accounts of rights, which are strongly focused on the notion of the Self. ${ }^{3}$ A Levinasian theory of animal rights, in particular, holds the potential to unsettle this traditional outlook. Indeed, from a Levinasian perspective, animal rights might properly be viewed as a model for the notion of human rights, since they capture the essential asymmetry of the ethical encounter.

\section{LEVINAS ON NON-HUMAN ANIMALS}

It will be useful to begin by examining Levinas' few explicit comments on the ethical status of non-human animals. The starting point for many discussions of Levinas' views on this topic is the essay "The Name of a Dog, or Natural Rights" in Difficult Freedom, ${ }^{4}$ in which Levinas reflects on his experiences as a Jewish internee in a German prisoner of war camp. The affection and enthusiasm of the dog, nicknamed Bobby, who befriends the internees, serves as a counter-point to the failure of the camp guards to acknowledge the humanity of their inmates. However, despite Bobby's ability to "attest to the dignity of the person," it is far from clear that Levinas regards Bobby himself as an ethical being. On the contrary, Levinas notes that Bobby has "neither ethics nor logos;" he lacks "the brain needed to universalise maxims and drives."

Levinas' comments on the status of animals in this essay remain somewhat ambiguous. He confronts the topic more directly in an interview with three graduate students published as "The Paradox of Morality." Levinas is asked explicitly in the interview whether animals demand recognition as ethical beings in a similar way to humans. His response does not completely reject the notion that animals make ethical demands upon us, but he makes it clear that these demands are not on the same level as those presented by other humans. "One cannot completely refuse the face of the animal. ... Yet the priority here is not found in the animal, but in the human face."

Later in the same interview, Levinas equivocates further about whether nonhumans can be described as claiming ethical status. "The human face is completely different and only afterwards do we discover the face of an animal. I don't know if a snake has a face. I can't answer that question." "He then goes on to reaffirm his previous suggestion that, while non-human animals are entitled to

3 For further discussion, see Jonathan Crowe, "Self and Other in Ethics and Law: A Comment on Manderson" (2008) 33 Australian Journal of Legal Philosophy 145.

4 Emmanuel Levinas, "The Name of a Dog, or Natural Rights" in Difficult Freedom: Essays on Judaism, trans. by Seán Hand (Baltimore: Johns Hopkins University Press, 1990) [Levinas, Name of a Dog].

5 Ibid. at 152-153.

6 Tamra Wright, Peter Hughes and Alison Ainley, "The Paradox of Morality: An Interview with Emmanuel Levinas" in Robert Bernasconi and David Wood, eds., The Provocation of Levinas (London: Routledge, 1988) [Wright et al.].

7 Ibid. at 169

8 Ibid. at 171-172. 
some level of ethical respect, they clearly do not enjoy the same ethical status as humans. "We do not want to make an animal suffer needlessly and so on. But the prototype of this is human ethics. ... It is because we, as humans, know what suffering is that we can have this obligation."

Insofar as we can make sense of Levinas' position in these passages, his view would seem to be something like the following. Non-human animals may or may not have "faces" in the specific ethical sense examined in his writings, but they certainly do not present the same type of ethical demands as humans. We have an ethical duty to spare non-humans from needless suffering; however, this duty is not on the same level as the ethical concern we owe to other humans. How this sketchy account of the ethical status of non-human animals fits in with the rest of Levinas' theory is not immediately clear. My aim in the following sections is to outline a reading of Levinas' ethical views that enables us to better understand how non-humans figure in his account.

\section{LANGUAGE AND THE FACE}

Levinas locates the revelation of the Other in what he terms the face-to-face encounter. The notion of the face plays a central role in Levinas' first book on ethics, Totality and Infinity, ${ }^{10}$ and continues to occupy a prominent place in his second major work, Otherwise than Being. ${ }^{11}$ The face of the Other represents a kind of "epiphany," in which "the sensible, still graspable, turns into total resistance to the grasp." 12 In the "total nudity of [the Other's] defenceless eyes," the subject encounters a "primordial" demand for recognition. ${ }^{13}$

Levinas speaks at length in Otherwise than Being about the tactile qualities of the face. The face is "weighted down with a skin;" ${ }^{14}$ it breathes; ${ }^{15}$ it exhibits signs of youth and age; it is a face "with wrinkles." 16 At the same time, however, Levinas makes it clear that the face, as he conceives it, is neither a biological nor a phenomenological notion. ${ }^{17}$ The face is ethics, pure and simple. The face-to-face encounter represents the moment that one becomes primordially aware of the ethical responsibility one bears towards the Other. In a way, all Levinas' ethical writings are an attempt to represent, however fleetingly and imperfectly, the ineffable significance of the face.

In both Totality and Infinity and Otherwise than Being, Levinas draws a close connection between the face and language. ${ }^{18}$ The performative aspect of lan-

9 Ibid. at 172 .

10 Emmanuel Levinas, Totality and Infinity: An Essay on Exteriority, trans. by Alphonso Lingis (Pittsburgh: Duquesne University Press, 1969) [Levinas, Totality and Infinity].

11 Emmanuel Levinas, Otherwise than Being or Beyond Essence, trans. by Alphonso Lingis (Pittsburgh: Duquesne University Press, 1998) [Levinas, Otherwise than Being].

12 Ibid. at 194, 197.

13 Ibid. at 199.

14 Ibid. at 85,89 .

15 Ibid. at 89.

16 Ibid. at 88, 90, 93.

17 Ibid. at $87,88-9$.

18 Llewelyn, supra note 1 at 240-241. 
guage, which Levinas calls the saying [le dire], creates a common ground between Self and Other. In language, I create "the world in discourse," 19 admitting the Other to the world of my experience. I offer her "things that are mine." ${ }^{20}$ It follows that language is not merely "a system of signs." ${ }^{21}$ My use of language to address the Other requires me to confront and acknowledge her status as an irreducible ethical being.

Levinas' discussion of the tactile qualities of the face makes it clear that language is merely one dimension of the face-to-face encounter. He emphasises elsewhere that the word "face," as used in his writings, "must not be understood in a narrow way." The face is not "the colour of the eyes, the ruddiness of the cheeks" and so on. ${ }^{22}$ In a similar way, the face is not language, even in the performative sense reflected in the notion of the saying. On the other hand, it is far from clear whether any consistent separation could be maintained, in Levinasian terms, between the two notions.

The multi-layered character of the face-to-face encounter helps to shed some light on Levinas' equivocation about whether non-human animals have faces. Non-human animals cannot appeal to us through language in the same way as other humans. They do, however, have skin, eyes and other expressive features. They gaze at us and, in that gaze, we recognise the outward trace of another living being. No wonder Levinas hesitates. "I don't know if a snake has a face. I can't answer that question." 23

\section{FROM ALTERITY TO PROXIMITY}

It is useful at this point to examine two further notions that occupy key positions in Levinas' ethical theory: alterity and proximity. The former idea plays a central role in Totality and Infinity, while the latter holds a prominent place in Otherwise than Being. One might partially trace the development of Levinas' ethical theory in these two works in terms of a movement from alterity to proximity. This idea of an ethics in movement helps us to further explore Levinas' comments about non-human animals.

Levinas suggests in Totality and Infinity that the irreducible strangeness of the Other presents an unavoidable ethical demand, which radically resists definition. He argues that our sense of ourselves as individuals is necessarily bound up with our recognition of the ethical status of the Other. We initially become aware of our individuality by distinguishing ourselves from objects in our environment, which we appropriate and represent as aids to our enjoyment. Our awareness of objects leads to language, as objects are communicated and thematised. It also leads to an awareness of the Other.

We initially attempt to thematise other people in the same way as objects.

19 Levinas, Totality and Infinity, supra note 10 at 76.

$20 \mathrm{Ibid}$. at 76.

21 Levinas, Otherwise than Being, supra note 11 at 35.

22 Emmanuel Levinas, Entre Nous: Thinking-of-the-Other, trans. by Michael B. Smith and Barbara Harshav (London: Continuum, 2006) at 200 [Levinas, Entre Nous].

23 Wright et al., supra note 6 at 171-172. 
However, as soon as we purport to encapsulate the Other, it becomes clear that "the invoked is not what I comprehend;" the Other "is not under a category." ${ }^{4}$ The Other demands recognition because she resists thematisation; the other person, qua individual, cannot be reduced to a function of our own enjoyment. Our attempts to thematise the Other conflict with her fundamental "strangeness," her "very freedom." 25

Simon Critchley usefully connects Levinas' observations about the alterity of the Other with the epistemological problem of other minds. ${ }^{26}$ Suppose I hear someone crying out in pain and rush to her aid. When I get there, the person denies that she was in pain at all. How can I know whether the remark is sincere? Ultimately, I cannot: the other person's state of mind radically resists my knowledge. For Levinas, this radical resistance to understanding defines my encounter with the Other.

Levinas' focus on alterity in Totality and Infinity leads him to emphasise the asymmetrical nature of the ethical encounter. The subject apprehends the Other as both unpredictable and unreliable. This requires her to unconditionally assume responsibility for their interaction. The result is a relationship where the subject must conceive herself as holding the upper hand, whereas the Other is permanently situated as vulnerable. The encounter is defined by the subject's power over the Other: "the face speaks to me and thereby invites me into a relation commensurate with a power exercised." ${ }^{27}$

Levinas' depiction of the ethical encounter in Otherwise than Being continues to emphasise its asymmetrical character. However, the focus shifts from the radical distance between the subject and the Other, to the subject's primordial need to approach her interlocutor, expressed through the notion of proximity. Levinas makes it clear that proximity is not a spatial relation. Rather, it describes that "restlessness" of the subject that compels her to seek greater intimacy with and understanding of the Other. ${ }^{28}$

Proximity, for Levinas, is a movement without an end: no matter how much the subject strives to approach and embrace the Other, she is destined to find that their relationship is "never close enough." ${ }^{29}$ This striving to know and embrace the Other, like the relationship of alterity described above, is fundamentally non-reciprocal. It is a relationship where the subject finds herself obsessed with the being of the Other, without being able to assume or conceive of any reciprocal concern. ${ }^{30}$

\section{THE NON-HUMAN OTHER}

Non-human animals occupy a profoundly ambiguous position in the Levi-

24 Levinas, Totality and Infinity, supra note 10 at 69.

25 Ibid. at 73 .

26 "Introduction" in Simon Critchley and Robert Bernasconi, eds., The Cambridge Companion to Levinas (Cambridge: Cambridge University Press, 2002) at 25-26.

27 Levinas, Totality and Infinity, supra note 10 at 198.

28 Levinas, Otherwise than Being, supra note 11 at 82.

29 Ibid.

$30 \mathrm{Ibid}$. at 83. 
nasian movement from alterity to proximity outlined in the previous section. We can begin our discussion of this point by exploring the alterity of the nonhuman Other. Do non-human animals resist thematisation in such a way as to demand ethical recognition? Do they draw the subject into an asymmetrical relationship where the responsibilities of the parties are "commensurate with a power exercised"? ${ }^{31}$

It is useful to approach this question by way of an example. Suppose I hear a cat mewing persistently. I conclude the cat is in pain; my natural inclination is to examine the cat and its surroundings, in order to determine the cause of its suffering. Suppose, however, that I find nothing unusual. Can I know what the cat is experiencing?

There is a sense in which the outlook of the cat is even more alien to me than the perspective of another human being. As Thomas Nagel observes in a celebrated essay, any attempt I might make to imagine what it is like to be a cat or a bat or any other non-human animal quickly runs up against the limits of my own experiences:

Our own experience provides the basic material for our imagination, whose range is therefore limited. It will not help to try to imagine that one has webbing on one's arms ... To the extent that I could look and behave like a wasp or a bat without changing my fundamental structure, my experiences would not be anything like the experiences of those animals. ${ }^{32}$

There is, therefore, a sense in which non-human animals are prone to unsettle me and slip beyond my grasp. I am compelled to recognise them as strangers, insofar as their phenomenal experiences elude thematisation.

In another respect, however, the being of the non-human animal is more transparent to me than the being of another human. I recognise that a cat has experiences, needs and desires. The exact character of the experiences and needs may elude my understanding, but I nevertheless feel they are somewhat within my grasp. I provide my cat with food, water and a warm, enclosed place to sleep. Similarly, the cry of a human infant can often be understood straightforwardly as a desire for milk, sleep or touch.

A mature human, by contrast, has experiences, needs and desires, but also commitments, intentions, plans, interests, projects, collaborations and concerns. Whereas the needs of a cat appear relatively predictable, the plans and commitments of a human being are experienced as radically contingent, insofar as they depend upon individual attitudes and choices. The being of the cat is undoubtedly somewhat elusive and alien, but the essential character of the other human is radically inaccessible to me.

We might explore the encounter with the non-human Other further by reference to the notion of proximity, continuing along the ethical trajectory mapped

31 Levinas, Totality and Infinity, supra note 10 at 198.

32 "What is it Like to Be a Bat?" (1974) 83 Philosophical Review 435 at 439. 
out above. Does the subject's encounter with the non-human Other exhibit the type of restlessness or obsession that Levinas describes in Otherwise than Being? Does it reflect a striving for intimacy where the closeness of the encounter is "never close enough"?33 The question is complex, but the answer seems to be "no."

The non-human Other does not invite the type of complex and insatiable fascination that Levinas observes in interpersonal encounters. As we saw above, the being of the non-human Other eludes us, but it does so in a less complex and radical way than the being of the other human. We do not know what it is like to be a cat, but we nonetheless feel we have some measure of the cat's needs and desires. The gaze of the cat does not exert the deep and intractable fascination that we find in the other human.

It is tempting to conclude from this line of thought that non-humans are not ethical subjects within the meaning of Levinas' account. ${ }^{34}$ However, this would be too hasty. There is a good reason why Levinas himself does not give such an unequivocal answer. The non-human Other gazes at us and, in that gaze, we find something less challenging and all-consuming than the ethical demand presented by other humans. Nonetheless, we cannot simply dismiss it without another thought.

The gaze of the non-human Other may not obsess us, but it nonetheless contains an inescapable demand for recognition as a living being. It draws us into an unequal relation where we possess the upper hand. It casts our freedom into question; it challenges and problematises our position of power. As Levinas observes, "one cannot completely refuse the face of the animal." ${ }^{35}$ The ethical environment we inhabit does not reduce to a simple dichotomy of subject and object; it confronts us instead with the distinctive demands presented by different types of beings.

\section{THE ETHICS OF SUFFERING}

The notion of suffering plays an important role in Levinas' account of ethics. We must accept responsibility for the suffering of the Other. As Levinas observes in his seminal essay on "Useless Suffering" in Entre Nous, suffering is not a mere "datum," but rather something more primordial, akin to a "revulsion." 36 It reveals, immediately and powerfully, the vulnerability of the Other. "Suffering is a pure undergoing:" it does not merely frustrate or limit the freedom of the Other, but renders the victim entirely passive, situating her as nothing more than a "mere thing."

This understanding of the significance of suffering holds important implications for the ethical status of the non-human Other. Again, it is no accident that Levinas' comments on non-humans focus heavily on their capacity for suffering.

33 Levinas, Otherwise than Being, supra note 11 at 82.

34 Llewelyn, supra note 1 at 235-236.

35 Wright et al, supra note 6 at 169.

36 Supra note 22 at 78.

37 Ibid. at 79. 
"We do not want to make an animal suffer needlessly and so on. ... It is because we, as humans, know what suffering is that we can have this obligation." 38

We saw above that the non-human Other is not a mere thing; the gaze of a non-human is inescapably that of a living being. It follows that suffering, which situates the victim as a mere object, is an evil for non-humans. As Levinas observes, it is not purely or even primarily a matter of restricting the victim's freedom. It is the brutal reductionism of suffering, which situates a living presence as if it were a mere thing, that horrifies and revolts us. The non-human victim of suffering, no less than the human, calls out for both our recognition and our aid. ${ }^{39}$

We might explore this point further by reference to another example. Suppose that a stray cat, a domestic cat and a human are all afflicted with serious injuries that are causing them to suffer pain. The pain is of sufficient severity to prevent them from pursuing any significant range of normal behaviours. (We might call to mind, with Levinas, the "moan," "cry" or "groan" that alerts us to the suffering of another being: ${ }^{40}$ or, in the case of the cats, the plaintive and persistent mewing that beseeches attention and assistance from anyone who chances to hear it.)

Further suppose there are three options open to someone who encounters one of these creatures and becomes aware of its suffering. The first option is simply to allow the suffering to continue. The second option is to end the suffering by administering a drug that will cause swift and painless death. The third option is to first administer pain-relieving medication, and then undertake a medical procedure so that the creature can recover to a point where treatment is no longer necessary.

Let us first consider the stray cat. The gaze of the cat presents a primal, inescapable demand for recognition as a being capable of conscious experiences; we are compelled to acknowledge its suffering. Most immediately, as Levinas observes, the demand presented by the victim of suffering is "a demand for analgesia, more pressing, more urgent ... than a demand for consolation or the postponement of death." ${ }^{\prime 41}$ As a consequence, we are motivated to reject the first option and respond to its pain.

In the case of the domestic cat, the situation takes on an added level of complexity. Suppose we have just noticed that the cat, whom we thought at first to be a stray, appears healthy and well-groomed. We become aware, not only of the gaze of the animal, but also of the ethical presence of its human carers. In Levinasian terms, we find reflected in the eyes of the animal the faces of those who care for it. ${ }^{42}$ We are more likely, therefore, to consider the third option than in the case of the stray examined above, insofar as good conscience motivates us to acknowledge the cat's carers.

The case of the human, on the other hand, weighs upon us still more deeply. The gaze of the human obliges us to recognise her radical alterity, as someone possessing plans, intentions, desires and interests that are irreducible to our own.

38 Wright et al., supra note 6 at 172.

39 Levinas, Entre Nous, supra note 22 at 80-81.

$40 \mathrm{Ibid}$. at 80.

41 Ibid.

42 Levinas, Totality and Infinity, supra note 10 at 213. 
More than this: it fascinates and revolts us, drawing us into an ethical bond from which there is no clear prospect of relief. The human is a stranger in an unmistakably deeper sense than other animals. We can grasp, albeit incompletely, the suffering of a cat, by seeking external causes for the discomfort. The human, however, is infinitely more complex; she holds preferences and attitudes that slip radically beyond our grasp.

The gaze of the human signifies a contingent, shifting field of outlooks, commitments and responses. It beseeches us to respect the path she envisages for herself. It is for this reason we are strongly drawn to the third option. The immediate demand is for analgesia, but this, as Levinas notes, signals the opening of "the anthropological category of the medical," 33 with its technologically coded promise of a future to come. As with the previous case, we also sense in the gaze of the human the presence of those who care for her, adding an additional level to our ethical engagement.

\section{THE SOCIAL FOUNDATIONS OF ETHICS}

The preceding sections of this article have explored the nature of the ethical encounter with the non-human Other in light of Levinas' theory. I have suggested that non-human animals present irreducible claims for recognition as ethical beings, although these claims have a different character to those presented by humans. In order to move from this account of ethical experience to a theory of animal rights, it is necessary to explore Levinas' views on the relationship between the primordial nature of ethical experience and the conceptual structures of morality and politics.

Levinas emphasises the particularity of the ethical encounter. The face-to-face encounter may be described as particular in two distinct but intertwined senses. First, the experience of the encounter is primordial and, therefore, resists expression through general terms and concepts; and, second, the encounter generates a unique and inescapable responsibility that rests on the subject alone. These features of the ethical encounter seem to cast doubt upon the possibility of genuinely shared judgements about ethical significance. It is hard to see how the experience could be either genuinely shared by multiple subjects or accurately communicated between them.

Levinas' comments on this issue are elusive. However, he hints at a resolution in Totality and Infinity when he speaks about time as the deepening of ethics. Through repeated interactions with the Other, Levinas notes, "the alterity of each face increases and deepens ever more profoundly." The discrete encounters that make up ethical experience "do not link up with one another indifferently, but extend from the Other unto me." ${ }^{\prime 4}$ Each encounter with the Other involves an epiphany; over time, however, our repeated ethical encounters link together to form an overall conception of social life. We come to regard ourselves as oriented towards the social environment, assuming responsibility for the Other wherever we find her. In this way, the alterity of the face does not lessen with

43 Levinas, Entre Nous, supra note 22 at 80.

44 Levinas, Totality and Infinity, supra note 10 at 283. 
each encounter, but rather "increases and deepens" as each interaction resonates with previous experiences.

The above analysis enables us to understand how ethical discourse is possible. Social judgements about ethical significance arise from the coincidence of multiple ethical experiences synthesised by individual actors. ${ }^{45}$ They are social habits that carry with them the weight of repeated ethical encounters. It is these social judgements, which arise passively from the continuous sequence of social life, that form the basis for our reflective engagement with ethical questions. More than this: it is these social judgements that render such questions distinctively ethical, since they mark out ethically significant fields of action from other sites of practical reasoning.

At this point, Levinas' account of ethics raises a further issue. What is the relationship between our social judgements of ethical significance and the reflective process of moral reasoning? In order to engage in moral deliberation, we must translate the passive synthesis of ethical experience to a rational framework of principles and rules. However, the dynamic character of social judgement militates against such a reductive enterprise.

Levinas acknowledges this tension in Otherwise than Being by drawing an important distinction between the saying [le dire] and the said [le dit]. The saying is revealed through my interaction with the Other. It resists phrasing and therefore comes to my awareness only through the way it speaks to me in the ethical moment. The said, by contrast, comprises statements or propositions to which truth values may be assigned. As Critchley puts it, the said is "the content of my words," whereas the saying "consists in the fact that these words are being addressed to an interlocutor." 46

The said thematises and conceptualises, while the saying resists categorisation. It is tempting to conclude that the saying and the said are entirely alien to one another. However, Levinas resists this outcome. Although my responsibility for the Other is "prior to anything said," it is both necessary and possible that the saying be "thematised, that is, manifest itself, that it enter into a proposition and a book." " ${ }^{7}$ The saying must find expression in propositional form in order to support the possibility of justice, politics and law. ${ }^{48}$

Why are justice and law necessary? For Levinas, the answer lies in the phenomenon of the third party. The third party is the neighbour of my neighbour, who is one step removed from me in terms of the face-to-face; she is all those, other than the Other, who may be affected in some way by my response to the ethical encounter. The presence of the third party challenges me to universalise my relationship with the Other. It necessitates "assembling, order, thematisation ... the intelligibility of a system" ${ }^{\prime 9}$ - in a word, justice. If the subject and the

45 For further discussion, see Jonathan Crowe, "Levinasian Ethics and Legal Obligation” (2006) 19 Ratio Juris 421 at 425; Jonathan Crowe, "Dworkin on the Value of Integrity" (2007) 12 Deakin Law Review 167 at 175-178; Jonathan Crowe, "Existentialism and Natural Law” (2005) 26 Adel. L. R. 55 at $71-72$.

46 Supra note 26 at 18.

47 Levinas, Otherwise than Being, supra note 11 at 43-44.

48 For further discussion see Crowe, "Levinasian Ethics and Legal Obligation", supra note 45.

49 Levinas, Otherwise than Being, supra note 11 at 157. 
Other were alone in the world, the problem of justice would not arise. The third party, however, "interrupts" the proximity of the face-to-face. ${ }^{50}$

\section{MORAL BELONGING}

The appearance of the third party, by making it both necessary and possible for the subject to thematise her responsibilities to other people, signals a new question concerning moral belonging. Although I can never entirely evade the gaze of the Other, the presence of the third party makes it possible to avert the force of the ethical moment by shifting the experience onto the level of the said. It becomes possible to posit distance between ourselves and those on the edges of our ethical awareness. In such cases, the boundary between the saying and the said becomes blurred. It becomes possible to ask, "who is my neighbour?" I am able to decide whether or not to assume responsibility.

The appearance of the third party in the midst of the ethical encounter therefore signals an important question. Why should I choose to acknowledge the demands of other people at the limits of my sensibility? Levinas hints at a possible response in his comments about conscience. ${ }^{51}$ According to Levinas, "conscience welcomes the Other," accepting her into the ethical fold. My conscience does not override my freedom, but sits alongside it, making my spontaneity appear "arbitrary and violent" where it runs up against questions concerning justice. ${ }^{52}$ On this view, then, moral deliberation consists in reflective, good faith engagement with primordial social judgements of ethical significance.

The issue of moral belonging casts into sharp relief the potential tension between the demands of good conscience and good faith, on the one hand, and the human capacity for free moral choice, on the other. It is a matter of deciding who counts and why. Historical examples illustrating the seriousness of this issue are not hard to find. At various times, women, slaves and members of particular racial and cultural groups have been determined not to count for moral purposes. Blacks did not count in nineteenth century America; Jews did not count in Nazi Germany. Pervasive discourses of cultural rationalisation pushed them to the outer margins of ethics. It became all too easy not to count them.

Moral belonging, which arises in the context of moral deliberation, should be contrasted with what I would like to call ethical personality, which arises at the level of the saying. Ethical personality arises with our primordial apprehension of the demands for recognition presented by other people. We might say that the ethical demand is a demand for acknowledgement qua ethical personality. The content of the idea of ethical personality is ineffable, since it is wholly conveyed in the ethical demand. At the margins of ethical sensibility, however, due to the presence of the third party, ethical personality becomes embroiled in the political, giving rise to the question of moral belonging.

We might usefully return at this point to Levinas' essay on "The Name of a

$50 \mathrm{Ibid}$. at 150.

51 A. T. Nuyen, "Levinas and the Ethics of Pity" (2000) 40 International Philosophical Quarterly 411 at $416-417$.

52 Levinas, Totality and Infinity, supra note 10 at 84. 
Dog, or Natural Rights." There, Levinas describes how the gazes of "the other men, called free," who dealt with the internees, "stripped us of our human skin." 53 "A small inner murmur, the strength and wretchedness of persecuted people, reminded us of our essence as thinking creatures, but we were no longer part of the world." Such "social aggression," for Levinas, "shuts people away in a class, deprives them of expression and condemns them to being "signifiers without a signified'." ${ }^{54}$ In other words, the ethical personality of the persecuted individual falls victim to rationalisation and is repressed at the moral level.

In the situation described by Levinas, the cultural rationalisation that excluded him from moral belonging was perpetuated in Nazi dogma. Jews, it was said, were "subhuman;" for the greater good of the German people, they had to be repressed and exterminated. In this way, the Jewish neighbour is supplanted by the universal Jew; she is replaced by a pure analytical category. Institutionally excluded from moral consideration, members of such groups are pushed to the margins of social consciousness, perpetually situated as the third party.

We have seen in the preceding sections that non-human creatures present a primordial demand for acknowledgement as beings capable of having conscious experiences; in particular, our encounter with such a creature places on us a responsibility to recognise and respond to its suffering. Many common commercial meat-production practices would seem to clearly run counter to this basic ethical demand. How, then, can we explain the persistence of such techniques? The answer is twofold.

First, few humans encounter the affected creatures on a regular basis apart from those institutionally engaged in their exploitation. As such, the non-humans in question occupy the position of the third party in relation to most ethical agents; the problem of distance arises. Second, there is a form of cultural rationalisation at work in relation to the supposed need for meat and other animal goods for human sustenance. ${ }^{55}$ This discourse exploits the lack of proximity between the subject and the non-human; it bears noting that people frequently react with revulsion when confronted directly with meat-production practices and would be horrified to see such treatment directed at domestic animals.

Levinas comments in "Useless Suffering" that "the justification of the neighbour's pain is certainly the source of all immorality." 56 There are two important ideas in this statement. Levinas' remark emphasises the fundamental place of suffering in ethics, but it equally takes aim at the role of the said in covering over our ethical responsibilities. The idea of justifying my neighbour's suffering, according to Levinas, is an "outrage." ${ }^{\prime 7}$ In this sense, ethical responsibility entails guarding against the temptation to rationalise our actions, rather than engaging in good faith with the ethical demands of other beings. This is the challenge posed by the notion of moral belonging.

53 Supra note 4 at 152-153.

54 Ibid. at 153 .

55 It is beyond dispute that the consumption of meat is not necessary for human health. See Singer, supra note 2 at 184-188; Regan, supra note 2 at 337.

56 Levinas, Entre Nous, supra note 22 at 85.

57 Ibid. 


\section{ANIMAL RIGHTS}

I return, then, to my initial question: what can we say, in good faith, about the moral status of animals? By way of a conclusion to this article, I wish to suggest it is both possible and constructive to thematise the claim to recognition presented by non-human animals in the language of rights. Levinas' work issues a sustained warning against totalising forms of moral discourse, which threaten to submerge the particularity of the ethical encounter. However, Levinas does not portray moral questions as radically indeterminate; rather, he presents a nuanced account of the interplay between the saying and the said, emphasising their necessary role in supporting the moral community.

Levinas cautions us not to over-simplify the necessarily ambiguous relationship between pre-reflective ethical experience and the conceptual framework imposed in moral deliberation. It is not that moral concepts are somehow embedded in the experiential features of ethical life. Rather, they are layered onto the ethical context, mediated by the requirement of good conscience. In order to respond in good faith to the appearance of the third party in the face-to-face encounter, it is necessary to formulate a conceptual framework for pursuing justice that acknowledges ethical personality. This will inevitably involve recourse to concepts such as rights, duties, interests and so forth, but these ideas should be viewed as subsidiary to the pre-reflective ethical environment. ${ }^{58}$

We have seen that non-human animals present a primordial claim for recognition as sentient beings; the capacity for suffering, in particular, features largely in the ethical field generated by such encounters. This is a claim for respect qua ethical personality; it demands a particular mode of treatment. It seems natural to conceptualise this ethical relationship in terms of rights and duties. Duties, in this context, supply their bearers with other-regarding reasons for action; they are reasons I have because of what I owe to somebody else. We might justly speak of a moral duty to recognise and respond to the suffering of non-human animals; the correlative of this duty is a moral right.

It is important to be clear what is meant here by the notion of correlativity. The very idea of correlativity between rights and duties may seem problematic from a Levinasian perspective: indeed, as we have seen, Levinas strongly resists a symmetrical view of the ethical encounter. However, the notion of correlativity, as I use it here, does not imply ethical equivalence. There is a logical correlativity between rights and duties (at least where these notions are understood as other-regarding); analytically speaking, each is the analogue of the other. If I have a duty in respect of another person, that person holds a right in respect of me. If somebody else has a duty to me, I become, ipso facto, the bearer of a right.

However, behind this logical relation, which arises purely at the level of the said, lies the ultimate ground of normative discourse: the ethical priority of the subject's responsibility for the Other. It is my primeval duty to acknowledge the ethical personality of other sentient beings that gives rise to rights discourse. The opening of rights discourse raises the prospect that I, too, may have rights. However, it is only through reference to the rights of the Other that I can recognise

58 Costas Douzinas, The End of Human Rights (Oxford: Hart, 2000) c. 13. 
myself as potentially a rights-bearing entity: the type of thing, thematically speaking, to which rights might belong.

It follows that rights are always, in the first place, the rights of the Other: the formal correlativity of rights and duties is only possible insofar as I acknowledge myself as subject to an unconditional ethical demand. I, too, may bear rights; but my rights appear "arbitrary and violent" where they run up against my duties to other people..$^{59}$ The challenge of rights discourse, therefore, is to prevent the primordial claims of the Other from being submerged in the logical framework of rights and duties. As Levinas says, "the principal task ... consists in thinking the Other-in-the-Same without thinking the Other as another Same." ${ }^{60}$

The above analysis suggests that there are risks - as well as benefits - in ascribing rights to humans. Rights discourse provides a rich and versatile conceptual framework for recognising the social dimension of ethical personality. On the other hand, the availability of rationalisation as a technique of moral avoidance means that people may invoke the language of rights in order to evade their ethical responsibilities. Rights discourse may be used to acknowledge the Other; it may also be used to place the Other at a distance. People may assert the rights accorded to them as Other, precisely in order to keep the Other at bay.

As Levinas makes clear, the ethical encounter is essentially asymmetrical: it starts from oneself and projects outwards towards the Other. The strangeness of the Other prevents me from assuming a reciprocality of obligations. It is only where the Other reveals herself by assuming responsibility for aspects of our common world that a form of reciprocality is created. ${ }^{61}$ Moral discourse introduces a form of symmetry that is unthinkable in the ethical encounter. In this sense, it represents a potential barrier, as well as a necessary aid, to good faith engagement with ethical experience.

That is the problem of rights discourse as it applies between humans. It is a problem of which Levinas is keenly aware. The problem arises because individual humans play a double role in moral discourse: both Self and Other, hostage and captor, potential holder of rights and duties. Does the same problem arise when we ascribe rights to non-human animals? The answer must depend upon whether non-humans, like humans, may appropriate their putative rights as an aid to moral avoidance.

It is sometimes argued that, since non-humans are incapable of engaging in moral discourse and deliberation, they should not be regarded as holding moral rights. ${ }^{62}$ It is true that non-humans do not seem to qualify as moral agents, in any meaningful sense of the term. In the first place, it is questionable whether non-human creatures make anything akin to social judgements of ethical significance. Without such judgements, there can be no value, at least in the ethical sense examined here. Furthermore, the vast majority of non-humans appear to

59 Levinas, Totality and Infinity, supra note 10 at 84.

60 Emmanuel Levinas, Of God Who Comes to Mind, trans. by Bettina Bergo (Stanford: Stanford University Press, 1998) at 80.

61 Levinas, Totality and Infinity, supra note 10 at 214.

62 See e.g. Jan Narveson, “Animal Rights" (1977) 7 Canadian Journal of Philosophy 161; Jan Narveson, "On a Case for Animal Rights" (1987) 70 The Monist 31. 
lack anything approaching the human capacity for moral reflection. They therefore do not partake in the ontological separation of value and will that is central to human ethical experience and, accordingly, are not responsible for their engagement with any context of value that may appear to them.

However, the fact that non-humans cannot be characterised as moral agents does not mean they lack moral rights; it only means that they are not susceptible to moral duties. If non-human animals are not moral agents, they have no moral responsibilities; as such, they cannot engage in moral avoidance. At the same time, however, such creatures may still make ethical demands upon other beings with a greater capacity for moral choice. There is no contradiction in holding that a being may present ethical claims to others while not being susceptible to or answerable for such entreaties itself.

Non-human animals gaze at us from beyond the borders of the moral community, commanding but not commanded. There is no risk here of entrenching rights as a mode of moral avoidance: non-humans cannot exploit their rights to keep the Other at a distance, nor can we straightforwardly assert our own putative rights as a way of evading their claims against us. It follows that it is relatively unproblematic to acknowledge such creatures as bearers of rights. Indeed, from this perspective, the rights of non-human animals might properly be regarded as a model for human rights: what Levinas describes as the rights of a "stranger,"63 granted purely out of respect for ethical personality, without expecting or demanding anything in return.

63 Levinas, Totality and Infinity, supra note 10 at 77. 